\title{
Re-publicizing the Nation: Slavery and the American Revolution
}

\section{Ulusun Yeniden İlanı: Kölelik ve Amerikan Devrimi}

\author{
Aşkın ÇELIKKOL ${ }^{1}$ (1)
}

${ }^{1}$ Res. Assist. Dr., Istanbul University, Faculty of Letters, Department of Western Languages and Literatures, American Culture and Literature, Istanbul, Turkey

ORCID: A.Ç. 0000-0001-7474-1686

\section{Corresponding author:}

Aşkın ÇELIKKKOL,

İstanbul Üniversitesi, Edebiyat Fakültesi, Balabanağa Mahallesi, Ordu Caddesi No: 6 , Laleli, Fatih, İstanbul, Türkiye

E-mail: askincelikkol@gmail.com

Submitted: 14.02 .2019

Accepted: 28.03.2019

Citation: Celikkol, A. (2019). Re-publicizing the nation: Slavery and the American revolution. Litera, 29(1), 41-58. https://doi.org/10.26650/LITERA2019-0011

\begin{abstract}
July 4, 1776 marks the national beginnings of the United States and is celebrated as the date of its independence from the imperial dominion of the United Kingdom. This turning point in the history of the nation is accepted as the genesis of the American freedom that champions the unassailable rights of life, liberty, and the pursuit of happiness. Amidst the general enthusiasm for freedom, however, the existence of slavery stood out as the ultimate paradox which the new nation had to contend with. Contrary to the accepted historiographical explanations for the incongruous presence of slavery in this land of freedom, the article claims that the principles that defined the US citizenry also drew a racial boundary between white and black communities where whiteness, inflected by nationhood, was held to be coterminous with being American, while other (colored) identities were hyphenated incessantly. The first part of the article addresses the teleological and apologetic explanations for the slavery problem and argues against them by giving a detailed analysis of the inconsistent attitudes of the abolitionist politicians and communities towards African-American populations. The second part of the article studies the black responses to American freedom and Frederick Douglass's famous speech that excoriates the hypocrisies coiled in the founding principles of the nation.
\end{abstract}

Keywords: The American Revolution, Nation-state, Race, Slavery, Citizenship

\section{Öz}

4 Temmuz, 1776 tarihi Amerika Birleşik Devletleri'nin Birleşik Krallık sömürgesinden kurtulduğu ve ulusun temellerinin atıldığı gün olarak kutlanmaktadır. Ulusun tarihinde önemli bir dönüm noktası teşkil eden bu tarih, Amerikan özgürlüğünün değişmez ve tartışılmaz unsurları olan yaşam, özgürlük ve mutluluğa erişim haklarının başlangıç noktası olarak kabul edilmektedir. Ancak, genel özgürlük coşkusu içinde, kölelik gibi bir sorunun varlığı, yeni ulusun yüzleşmek zorunda olduğu nihai çelişki olarak göze çarpıyordu. Özgürlük ülkesinde varlığı eğreti duran kölelik müessesinin varlık nedenlerini açıklayan genel ve kabul edilen tarihsel açıklamaların aksine, mevcut çalışma Amerikan vatandaşığını tanımlayan ilkelerin beyaz ve siyah topluluklar arasında ırksal bir sınır çizdiği ve Amerikan vatandaşsığını, Amerikalı olmayı, beyazıı ile özdes tuttuğu noktasını savunmaktadır. Makalenin birinci kısmı, kölelik sorununa açılamalar getiren teleolojik yaklaşımlara karşılık olarak, kölelik karşıtı politikacıların ve toplulukların siyah topluluklara karşı sergiledikleri tutarsız tavırları incelemektedir. İkinci kısımda ise, Amerikan özgürlüğüne siyahların verdikleri tepkiler ve Frederick Douglass'ın ülkenin kuruluş ilkelerindeki mürai fikir ve uygulamaları eleştirdiği konuşması irdelenmektedir. Irk, etnik köken odaklı ulusalc yapılar ile Amerika Birleşik Devletleri'nin sosyopolitik ve sosyokültürel temellerini olușturan kölelik ve Ulusal Bağımsızlık Günü gibi tarihsel dönüm noktalarının vatandaşlık kavramı ile kurduğu karmaşık ilişkilerin ele alınması çalışmanın amaçları arasındadır. Sonuç olarak bu çalışma, ulusal aidiyet ve kimlik yapılarının toplumsal tezahürleri doğrultusunda ırk ve ırkçılık konuları üzerine bir tartışma sunmaktadır.

Anahtar Kelimeler: Amerikan Devrimi, Ulus-devlet, Irk, Kölelik, Vatandaşlık 
The coexistence of two world views, often contradictory, one expressed in words and the other shown through actions, is not always due to bad faith. Bad faith may be a true and satisfactory explanation for single individuals, or even small groups, but it is neither a true not satisfactory explanation when this contradiction is found in large numbers of people. Then, this contradiction must be the expression of deeper contradictions at a historical and sociological level.

Antonio Gramsci, II Materialismo storico

\section{Introduction}

1776 is perhaps one of the most cherished and equally the most convoluted year in American national history. After waging a successful war against the British Empire and ridding itself of its imperial dominion over the North American colonies, America rallied around a certain cause: the formation of a new nation in the wake of the revolution. As is the case with many revolutions, the American revolution was likewise witness to rapid and radical transformations on social, political, cultural, and economic levels which consequently planted the first seeds of "nationhood" among the American people. As to the social structure and the official ideology of the revolution, many historians agree that it was indeed a bourgeois republic, though not a fully-fledged one, that was being forged at the time. Free settlement of the Western territory, redistribution of loyalist estates to men of small means, abolition of primogeniture and entail, extension of franchise and attempts at secularizing the established churches all point in the direction of a leveling democracy that would easily interlace the American Revolution with other bourgeois administrations (Jameson, 1973, pp. 9-18). Furthermore, the centrality of the market in the lives of Americans was another undeniable fact and facet of the democratic bourgeois society. The commercial activities and exchanges that took place visibly in this sphere had corrosive effects on the traditional patronage and hierarchical monetary confidences. Americans were free, equal and alike to the extent that they participated and were involved in the market transactions for their individual ends (Wood, 1993, pp. 310-340). It would be a misconception nonetheless to assert that there was a far reaching and a thoroughly built bourgeois public at the time. The traditional patronage and paternalist economic systems were still in effect and played significant roles in individual relations especially in the south end of the country. Even though the Northerners were exempt from such overt practices of feudal paternalism, there still existed a subtle presence of the system within the domestic realm of the family. Under the circumstances then, the American society could best be dubbed as protobourgeois with some carry-overs from the feudal system. 
Traditional feudal societies were structured around a metonymy of head and body as the feudal lord, the monarch or god would constitute the decision making mechanisms, shaping and dictating the numerous functions and movements of the huge body of society beneath them. The hierarchical relations between the ruler and his subjects were founded on the premise that the head, the legitimate organ, was the incarnation of the public; the ultimate medium of representation for the rest of the society. In such a structure, the land and the manor house were constitutive of the public sphere of the peasants or of those animal laborans to borrow the term from Hannah Arendt. Those who worked with their hands and toiled hard for the production of the necessities of life were doing so in the public-private realm governed by a superior publicity of landed gentry. The privileges of education, intelligence, decorum and wealth were the very particularities that stirred the scorn of the aristocracy towards those commons who lacked such entitlements. What the American Revolution did, as Gordon S. Wood asserts, was to tear the fabrics that held the old society together in terms of haves and have-nots (Wood, 1993, pp. 6-7). By the end of the war, the American society began to reshape itself in accordance with the very value that was disliked by the genteel class: labor; a virtuous and a productive activity not corrupted by the feigned morality of the gentry. Education, intelligence, decorum and wealth all came to be refigured around this single principle and benevolent act of laboring. With laboring came equality, and the sovereignty of the public. The head and the body, the public and the private joined in unison for creating the American citizen.

In a Habermasian twist, the impervious line that strictly divided the public and the private realms and subsumed the latter's agency under the authority of the former category, slowly became a porous one that "put the state in touch with the needs of the society" (Habermas, 1991, pp. 30-31). The governmental institutions (courts, schools, churches, hospitals and prisons) were connected to the private sectors of conjugal family and home. What united these previously separate realms was the world of letters; the circulation of pamphlets, newspapers, journals. To put it briefly, printing, by extension fastened together the parochial, buoyant "island communities" and forged them into a homogeneous American society. Benedict Anderson's "imagined community" relies on just such an extensive distribution and circulation of printed works among a nominally uniform body of literate subjects. For Anderson, the technologies of "print capitalism" hastened the recognition of fellow subjects as existing within the same space and time (Anderson, 2006, p. 22). This 
recognition would serve to address and identify with other participants whose utter strangeness and unfamiliarity would be overcome by the relatedness of this kind of public sphere of letters. As such, publicity gave spur to democratic and national tendencies in the form of "imagined", abstract sameness, and the peoples in the United States shed their differences (not race or gender) and their individual aspirations for the benefit of the greater public. This principle of negativity as Michael Warner suggests, presupposed a virtuous American who disliked pomp, luxury and who exhibited an individual disinterestedness that would further the interests of the homogenous whole. In a similar vein, Charles Ingersoll in 1810 defended America's national character against the rest of the world, and gave his reasons for the exceptional status of his country in the following words: "Luxury has not yet corrupted the rich, nor is there any of that want, which classifies the poor. There is no populace. All are people. What in other countries is called the populace, a compost heap, whence germinates mobs, beggars, and tyrants, is not to be found in the towns; and there is no peasantry in the country. Were it not for the slaves of the south, there would be one rank" (Wood, 1993, p. 348).

Ingersoll, probably unwillingly, touched upon the delicate and hot button issue of slavery and just like his contemporaries, preferred to remain silent on the incongruous presence of bondage amidst the 'most egalitarian nation' in the world. This article argues that the principles that defined the new American; the independent, virtuous and the responsible citizen that was first chanted into being by The Declaration of Independence, were at the same time drawing a color line, both imaginary and real, between the white and the black communities. The American Revolution paved the way for the creation of a new publicity, new modalities of visibility and invisibility, parameters of inclusion and exclusion, notions and creeds that gave hue to the emergent American citizenship. In this respect, the preamble "We the People" presumed a collective subjectivity gravitating toward the center of the public domain certain populations while branding the others with an immutable invisibility, and as eternal vessels of contaminations. ${ }^{1}$ This article studies the pathways and the

1 It would be perhaps erroneous to claim that in the antebellum years a racial, discriminatory line was prevalent in both the Northern and the Southern regions of the United States. However, during the postwar years, it took on a different hue, tinged with abstract, naturalized, ahistorical, and eternal reverberations. Benedict Anderson places racism on a similar metaphysical plane and his insights on nationalism and racism may prove pertinent for the condition of the blacks after the American Revolution: "... nationalism thinks in terms of historical destinies, while racism dreams of eternal contaminations, transmitted from the origins of time through an endless sequence of loathsome copulations: outside history. Niggers are - thanks to invisible tar-brush, forever niggers; Jews, the seed of Abraham, forever Jews" (Anderson, 2006, p. 149). 
watershed moments in American history, specifically the four decades following the declaration of independence, in which racial configurations and discriminations were first deployed both in public and private spheres and subsequently evolved, and crystallized into racist practices.

\section{The Ontogeny of Segregation}

The historian Gary B. Nash's reading of the American Revolution sheds some light on certain unresolved dilemmas, especially on the starkest dilemma of slavery, which is still a difficult issue to tackle, that proved inconsistent in a nation surged by the ideals of equality, fraternity and freedom. In The Forgotten Fifth, Nash attempts to locate the silent black actors in the War of Independence and draws the conclusion in the chapter titled "Could Slavery Have Been Abolished?" that slavery could indeed be abolished under the existing favorable conditions. He enumerates five factors that would quicken the abolition rather than impend its realization (Nash, 2006, pp. 6977). First among these is that the American society would disentangle itself from a blood-drenched labor system that was at odds with the burgeoning capitalist wage labor of the Northern markets. Secondly, contrary to the long held belief that the south, especially the Lower South, had the power to impose its will on the whole nation concerning slavery, Nash claims that far from making that formidable claim, the Lower South was actually vulnerable both in politics and economy and depended on the Northern states. Another crucial factor would be the rise of the environmentalist thought in the American society which would define man not according to his biological, so called innate qualifications but within a context of his environment as the prime variable in deciding his fate. This new line of thinking which championed the equality of men or rather his ability to reach it - not constrained by biology - was actually crucial for the colonists to lay claim to independence against the British. Why not extend this egalitarian thought to the people in bondage? The sale of the Western lands and thus the prospect of overcoming the fiscal crisis of the South lest slavery was abolished in the Southern states would rid the nation of another problem and clear the way for an effective and thorough emancipation of the African American populations. If all these reasons would not suffice to dethrone slavery, then the United States had the French and the British examples of slave rebellions, a bloody one down in St. Domingue, to remind the Americans of the imminent threat lurking within their yet to be delineated borders. 
Did the revolutionary Americans take notice of all these facts and factors? For Nash, they did indeed, among whom were some prominent and well-known Americans criticizing the immorality of slavery and the apparent, undeniable inconsistency of its presence in a land of freedom. The founding fathers James Madison, George Washington and Thomas Jefferson all toyed with the idea of abolition during the initial phases of the revolution but subsequently fell into silence or adjusted their views about this vital issue. The simple question that begs not too simple an answer is why. Why was the infant state incapable of demolishing a blight that was defaming the glorious War of Independence if the conditions such that Nash describes were in favor? Why did the founding fathers who devised, and implemented the first constitutional drafts of the nation not press their anti-slavery arguments rigorously? What can one discern in this blank silence? Nash partly gives the answer to these questions. By explaining Madison's dilemma and his reluctance to take an active part in the process, he attributes the same unwillingness to Washington and Jefferson. In other words, Nash explains away that the crucial and troubling question that ailed these figures was not when but how (Nash, 2006, p. 118). The abolition of slavery was not the foremost concern of the founding fathers, but how to deal with the emancipated blacks afterwards, the need to integrate them to the society at large and outline their rights within the public sphere constituted their basic concerns.

The controversy that surrounded the institution of slavery is much more complex than Nash demonstrates in The Forgotten Fifth. The South's economic and political power was something that could not be ignored by the Northerners and the assertive voices of the Southern slaveholders were heard in the chambers of the recently formed government. Even though the Lower South was weak, Virginia and Carolina were still potent states to impose their wills in the senate house. In The Writings on the North American Civil War, Marx and Engels aptly claim that before secession took place in 1861, Southern delegates had been an influential bloc in directing the American political landscape (Marx \& Engels, 1964, pp. 4-10). Moreover, slavery's abolition was not just a fiscal matter that could be solved by western expansion and land sales as Nash had suggested, but it was in fact the very artery that pumped life into the South's power dynamics. ${ }^{2}$ In this regard, the deliberate silence of Madison, Washington and Jefferson could be better discerned and augmented by the fact that

2 The institution of slavery was indispensable for the Southern economy and politics, yet it was also a vital mechanism through which social life, public and private, defined itself via the discourse of paternity and thus the Southern identity depended on the subjugated, infantilized figure of the slave. 
Washington and Jefferson were slaveholders themselves in their lifetimes and Madison freed his slave Billey and left him in Philadelphia because he was afraid that "Billey was so infected with the contagion of liberty that he would be a malign influence on his slaves in Virginia" (Kaminski, 1995, p. 268). Thomas Jefferson more than others explicitly compounded the fact that although all men were free, whites and blacks still could not be thought equals as the latter were "inferior to the whites in... mind and body," which was followed by a more precise definition that "nothing is more certainly written in the book of fate than that two races, equally free, cannot live in the same government" (Jefferson, 1905, I, p. 77).

Jefferson's observations were a far cry from being idiosyncratic, for many citizens - despite their libertarian ideas - also held similar convictions. With the spread of republican ideals, especially with the extension of suffrage to all free citizens of the republic, "Northern whites began to view black voters with increasing apprehension, unwilling to accept the equality that suffrage and citizenship dictated" (Wood, 2011 p.172). In the early 1800 s, the American Colonization Society, publicly supported by Thomas Jefferson and funded by James Madison, sought to find a solution to the "problem" of growing numbers of free blacks and launched the campaign to resettle them in an independent country in Africa. Finding support from some slaveholders and abolitionist whites, the Society eventually chose Liberia for its back-to-Africa movement, and purchased strips of land, with the help of coercion, from local tribal leaders. The campaign did not meet the expectations as it never became popular with the free black populations and there were oppositions within the cabinet for moral reasons and for practical reasons that the resettlement project would considerably dwindle the labor force vital for the US economy.

The segregation efforts such as the founding of a new, distant nation for the slave populations found counterparts in almost all walks of life; in public, private, secular and ecclesiastic organizations racial discrimination was widespread and strictly observed. One can detect the ontogeny of segregation as early as 1790 , a decade and a half after the year 1776, and its implementation by the pride-stirring new institutions of the nation such as hospitals and penitentiaries as well as the old institutions of prison houses and churches. Virginia's Penitentiary House was closed to blacks, the hospitals in New York had separate wards for the patients. The pattern of apartheid in the prisons followed the general rule, where it could be least expected, and in Philadelphia black and white prisoners ate separately and a "white servant, no 
matter who, would consider it a dishonor to eat with colored people" (Jordan, 1968, p. 416). Things were not very different in loftier public institutions as theaters would generally restrict the black audiences to the gallery and Masonic lodges did not admit any black members. The members of the Congregational Church in North Bridgewater, Massachusetts would see to the measure that "The Parish will take to prevent the blacks from occupying the seats appropriated to the use of the white people, so as to prevent any disturbances in time of public worship," and the members issued a decree that "the side galleries and the seats in the body [should be for the use] of the white people, and the seats in the porch above to the use of the blacks" (Jordan, 1968, p. 418).

The most ironic of all and perhaps the most tragic one was that blacks and whites could come together as equals only during funerals and in cemeteries. The funeral of Mrs. William Grey of Philadelphia in 1791, attended by numerous blacks and whites of the city, provoked the following remark from a local newspaper: "a pleasing instance of total indifference to complexion." Benjamin Rush, an optimistic supporter of equality, seized on the moment's sentiments and hoped for "the partition wall which divided the Blacks from the Whites will be still further broken down and a way prepared for their union as brethren and members of one great family" (Jordan, 2012, p. 416). Rush's hopes did not come to much since this divisive practice was not due to an irrational, color prejudice that could be eliminated as though it was a mere superstition. The earliest and the most vehement pro-abolitionist denomination in the United States, Quakers, or The Society of Friends as they used to call themselves, showed such prejudiced, inconsistent attitudes towards their black brethren. The Society of Friends labored to educate the black children and brought them to their meetings, however, they failed to give full membership to their oppressed brethren to join their congregation. Some friends even deliberately tried to exclude them. A controversy in Pennsylvania in 1791 over a light-skinned woman's membership brought to the fore the covert prejudices that the Society fought in the first place. This apparent contradiction did not go unnoticed and a member of the Society, Joseph Drinker made the point to Philadelphia Friends in 1795 in an unambiguous language: "There is no People in the world that I ever heard of, who hold forth such Liberal Universal Principles as the People called Quakers, and yet to my astonishment they are the only People I know who make any objections to the Blacks or People of Color joining them in Church Fellowship" (Jordan, 1968, p. 421). Despite the admonishment of Drinker and few people like him, the irony remained and the most 
actively egalitarian religious sect in the country was one of the least interested denominations in the country in accepting their colored brethren among them. The wedge was pushed further as Philadelphia Monthly Meeting in 1805 decided to hold no more meetings for the colored as "Friends upon weighty deliberation, were united in the belief that the service of them was over, and they have now several places for worship of their own" (Jordan, 1968, p. 422). One of the first historians to study slavery issue in Americas, Frank Tannenbaum's insight may explain some of the reasons behind the Society's dilemma. Tannenbaum posits that the prevalent association of slavery with African-Americans in the United States, and in a number of states the utmost care taken to keep them in that position or reduce them to bondage if free had repercussions on segregative practices (Tannenbaum, 1963, pp. 65-70).

Manumission was scarce among the Southern slave holders and even though there were some examples, there rose further impediments to make such acts ineffective. In Mississippi, Alabama, and Maryland manumission by will was void. In Georgia in 1801, a slave owner was charged two hundred dollars for attempting to free his slave without the prior authorization of the state legislature and the slave's bondage continued as before. In North Carolina in 1836, if a slave could attain his freedom despite the various obstacles, he had to leave the state within ninety days, never to return, the failure of which would be enough to return him to slavery (Tannenbaum, 1947, pp. 70-71). Besides such direct restrictions on slave's freedom, the other indirect restrictions were also in practice. To name a few and well known examples: the testimony of the slaves in the courts were void, they could not own property and their marriage was denied social cognizance. African-American individuals were to be kept as separate beings, even liberated, not to be regarded as free moral agents.

As the percentage of the free blacks of the total black population in 1790 rose from 8 percent to 13 percent in 1810, despite the pending difficulties, the dislike and prejudice of the white communities, especially in the South seemed to parallel this rise. More permissive and lukewarm Northern states did not follow the strict regulations as their counterparts did in the South. However, there was a considerable resentment against the black voting throughout the region. Interestingly, the disfranchisement of the blacks did not enter the state legislations of some border states immediately. In 1780, Delaware and Maryland restricted the voting rights of those that were emancipated after a certain passage of acts when in the early 
nineteenth century all free blacks were disfranchised in those states. Similarly, Kentucky's first constitution had no such ban in 1792 but the second one in 1799 did. The transition from enfranchisement to disenfranchisement becomes more complex as Winthrop Jordan suggests that throughout the "free states free Negroes were legally entitled to vote," though the local customs kept them away from the polls, yet "It was in the nineteenth century that they were pointedly excluded," as Ohio in 1802 and New Jersey in 1807 "were the first free states to disfranchise them by law" (Jordan, 1968, p. 412).

Shortly after the Revolution, Americans, haphazardly but with detectable acceleration began to legislate the black into an ever-shrinking corner of the American society. After a brief period of flexibility, there came the trend of tighter restrictions on the slaves and especially on the free blacks to ensure the separation of races at places of social gathering. It would not be an impertinent point to make then that even though some concessions were made in favor of the blacks during the revolution and a serious concern was shown over the presence of slavery, still out of that very concern emerged a racist society whether consciously or unconsciously.

Eugene D. Genovese makes an important point in his comparative study of slavery in the New World in terms of the social inequality based on racial assumptions and needs an extensive quotation at this point:

Color prejudice, blood pride, and other forms of ethnocentricity preceded slavery and prepared the way for racism, understood as an ideology of oppression and subordination. The transition from the former to the latter occurred by means of such institutionalized mechanisms of discrimination as the slave codes, the plantation regime, and the organized caste restrictions against freedmen. But whereas in some societies these discriminations lost some or much of their force after general abolition, in the United States abolition reinforced them. (Genovese, 1988, p. 110)

Whether racism preceded slavery and thus became a justification for the enslavement of the black race or racism was the outcome of slavery, a system, which attached debasing racial etiquettes to those in bondage, is an issue well treated and studied by numerous scholars, but still a complex one to draw certain conclusions 
about. What is interesting and should be highlighted is the fact that the imminent freedom of the blacks after the revolution invoked and resuscitated the racial fears and even created new avenues for their practices.

\section{The Fifth of July and a Counter Republic}

Blacks in America, whether granted manumissions or in bondage, were aware of the stark inconsistencies the revolution harbored. The $4^{\text {th }}$ of July, 1776, the glorious day of independence, was rejected by blacks on the grounds that the date was tantamount to freedom of the white race at the expense of the black race's submission. Peter Osborne, the black pastor of the New Haven African Church in Connecticut, delivered a speech on July 5, 1832, unfolding the intricacies wrapped around the date of national celebration.

On account of the misfortune of our color, our fourth of July comes on the fifth; but I hope and trust that when the Declaration of Independence is fully executed, which declared that all men, without respect to person, were born free and equal, we may then have our fourth of July on the fourth. (Osborne, 2003, p. 8)

The Fourth of July became a symbolic site of contestation in which the issues of freedom, equality, economic opportunity, social recognition were debated and at times violently demanded. Nat Turner's slave rebellion, also known as the Southampton Insurrection, was one of those bloodstained moments. Born in a slave plantation in Southampton County, Virginia, Nat Turner was an intelligent, religious young man who learned how to write and read at an early age and was a favorite figure of the slaves in Turner plantation. Allegedly, Nat Turner would have visions that would inspire him to take actions towards the liberation of the blacks in America. A self-proclaimed black Moses, Turner's visions gave him a religious authority as well as certain dates for his long-planned and awaited insurrection. Originally planned to be launched on July 4, 1831, Turner's rebellion eventually began on February 12, 1831 after he witnessed a solar eclipse. Supported by 70 free and slave blacks, Turner and his rebel contingent attacked plantation houses and allegedly killed 60 white people. The local militia and the federal army units rapidly suppressed the insurrection and subsequently went on a spree of killing innocent black people in the process. Nat Turner was captured on October 30 and was hanged on November 5. 
Contrary to some claims as to the mental health of Nat Turner, as evinced by Turner's so called divine visions, Turner's rebellion was an organized political act that revealed an awareness on the part of black Americans of the true nature of the Fourth of July. Turner's initial choice to start the rebellion on that particular day was a deliberate attempt to attack not only the economic structures of slavery but also the symbolic networks of subjugation. For the black abolitionist Sojourner Truth, "Independence Day symbolized both the promise of freedom and its denial" (Colaiaco, 2006, p. 9).

The Weekly Anglo-African seconded Sojourner's observation and published an article criticizing the hypocrisy accompanying the date: "The people generally do not understand why one should celebrate a day that ... brought freedom to whites and slavery to colored people" (Colaiaco, 2006, p. 10). The most blistering and well-known criticism came from Frederick Douglass, an ex-slave who earned his freedom through much toil and suffering. As Douglass was an international and historical character whose orations and writings shaped the abolitionist campaign during its early years and continue to influence the debates on racism even today, it is more than pertinent to address his What to the Slave Is the Fourth of July? speech at length.

Frederick Douglass was born into slavery in Talbot County, Maryland. At the age of twelve, he learned the alphabet from the kindhearted wife of Hugh Auld, yet, his tutoring was abruptly stopped after Auld scolded his wife for teaching Douglass how to write and read. It was a bad and a dangerous influence on the slaves, Auld claimed, that might implant rebellious ideas such as freedom. Douglass continued his education in secret, sometimes by tricking the children playing on the dock into teaching him words, and by reading the scraps of newspapers and journals he would retrieve from the streets. His relatively relaxed term under Auld family ended after he was sent to a poor farmer Edward Covey who was known to be a notorious slavebreaker. His physical confrontations with Covey left indelible marks in Douglass's soul, however, they also conferred on him a certain authority and recognition and admission on the part of the slave-breaker of Douglass's physical, intellectual and moral strength. Douglass eventually attained his freedom thanks to the escape routes of the famous "Underground Railroad," and settled in New York City. Until his death in 1895, Douglass delivered numerous anti-slavery speeches to national and international audiences. Despite his acclaimed status, it may not be erroneous to claim that Douglass never felt himself to be an integral part of the white, pro- 
abolitionist society. The same claim could be made for the white audiences as they viewed Douglass not as a human being, but as a sublime force beyond human cognition. A journal, after one of Douglass's fiery orations, likened his voice to the thunderous sounds of the Niagara Falls and his mien on the stage to this gigantic natural phenomenon (Patterson, 1999, p. 244). ${ }^{3}$

In What to the Slave Is the Fourth of July? address, such division between himself and the white audience, and a sense of alienation from the ideals the Fourth of July promulgates become apparent. At the commencement of his speech, Douglass makes it explicitly clear that Independence Day belongs to white Americans, to abolitionist citizens gathered in the hall to listen to Douglass and to the slave owners in the South.

It is the birthday of your National Independence, and of your political freedom. This, to you, is what the Passover was to the emancipated people of God. It carries your minds back to the day, and to the act of your great deliverance; and to the signs, and to the wonders, associated with that act, and that day. This celebration also marks the beginning of another year of your national life; and reminds you that the Republic of America is now 76 years old. I am glad, fellow-citizens, that your nation is so young. (Douglass, 2015, p. 1)

The repetition of the possessive determiner "your" functions as the constant reminder of what belongs to white American citizens: "National Independence, political freedom, great deliverance, national life, nation." Douglass deliberately avoids associating with the homogenous group and the set of creeds until he introduces his presence by the phrase "fellow citizens." Michael Warner, in "Publics and Counterpublics," specifies seven characteristics of public or how publics are formed through interactive processes of addressers, addressees and discursive fields. For our purposes here, the first two senses of public formations, that is, public as a

3 Orlando Patterson believes that such dissociation from humanity, from the corporal reality of the black body has extended into the twenty first century. Famous athletes such as Michael Jordan and Dennis Rodman have been labeled with unhuman qualities and been elevated to the status of an Olympian demigod. This god, however, would not be the god of the Sun, Apollo, who would represent reason, truth, and morality. The god rather would be Dionysus, whose divine role would consist of entertaining the other gods and the humans by letting their appetites get the better of their critical faculties. In this respect, African-Americans have played the American Dionysus role for the strict, demanding atmosphere of an Apollonian, white-collared, capitalist system. 
"self-organized" structure and as "a relation among strangers" should be given some consideration. The self-organization of a public becomes possible thanks to a "space of discourse organized by nothing other than discourse itself." Public as such is an autotelic space, closed in on itself letting no exterior authority or meaning to have a say on the discursive, interactive field generated by the audience and the speaker. In this first characteristic, Warner mentions the absence of any state influence and for that matter of governmental organization (Warner, 2002, pp. 413-414).

The audience or the addressees Frederick Douglass engages with in a reciprocal manner can be said to constitute the discursive, in-itself public, which generates or circulates meaning(s) away from the inquisitive eyes of the state. In other words, they are free to support a cause unwarranted by the state and its courts and thus form a counter public discourse around the abolition of slavery. No matter how counter public it claims to be, Douglass shatters the illusion by revealing the ties between the abolitionist group and the pro-slavery state. Douglass lists the privileges both the abolitionist group and the state sustain and enjoy under the aegis of freedom.

The second feature of Warner's publics, "relation among strangers," may be a pertinent point to explicate Douglass's final remark. For Warner, the function of "strangerhood" is different in today's publics from its ancient use. Contemporary publics treat strangers not as exotic, mysterious others whose "disturbing presence requiring resolution." On the contrary, publics of the modern world view strangers as belonging to "our world" and their presence is necessary to imagine and to make sense of any communal organization:"A nation or public or market in which everyone could be known personally would be no nation or public or market at all" (Warner, 2002, p. 417). In Douglass's case, ancient and modern utilizations of strangers seem to be working in an alternating and complementary way. As mentioned above, the predominantly white, abolitionist group's approach to Douglass was marked by feelings of awe and admiration that refused to ascribe human traits to the man on the pulpit. In this regard, Douglass was elevated to the status of the mysterious, exotic wanderer of ancient times and was treated not as a constitutive part of the community but as a presence that necessitated a solution. As What to the Slave Is the Fourth of July? proceeds, Douglass aims at breaking and inverting the binary that associates white race with humanity while ascribing inhumane qualities to black race. Douglass depicts a scene in which "man-drover" armed with a bowie knife and a pistol drives the sad procession of slaves while "savage yells" and obscene curses 
pour out of his mouth. The poor and wretched slaves, old and infirm men with "locks thinned and gray," young mothers "whose shoulders are bare to the scorching sun, her briny tears falling on the brow of the babe in her arms," proceed slowly under the rude and brutal gazes of American slave-buyers. This most "fiendish" and "shocking" spectacle, Douglass maintains, is what transpires in "the ruling part of the United States" (Douglass, 2015, p. 11).

By debunking the images of humanity attached to racial configurations, Douglass problematizes the figure of stranger and thus impedes the process of identification that renders the imagination of a nation possible. In lieu of the racially different figure of a slave or of a free black man as himself, he positions the white slave-driver at the center of strangeness and by implication holds such figure of oppression, not the oppressed slave, to be an integral part of American identity. In another instance of defamiliarization, Douglass further complicates the bonds of recognition and filiation the audience maintains with the founding fathers. Commencing with an eloquent praise of the deeds accomplished by those figures of eminence, he continues with a quadrant.

Is this the land your Fathers loved,

The freedom which they toiled to win?

Is this the earth whereon they moved?

Are these the graves they slumber in? (Douglass, 2015, p. 12)

In the following pages though, Douglass changes his tone from acclaim to ranting criticism and yet with another stanza, he negates his initial position of commendation.

Then, I dare to affirm, notwithstanding all I have said before, your fathers stooped, basely stooped

To palter with us in a double sense:

And keep the word of promise to the ear,

But break it to the heart. (Douglass, 2015, p. 17)

Frederick Douglass's highly paradoxical, and for some hypocritical, positions and statements throughout the whole speech may be explained in more than one way. It may be a rhetorical device and tactic to draw attention to the inconsistencies in the 
American society and stir the people to action via its provocative language. Or, perhaps, Douglass was feeling the pulse of the public at the time and was just reflecting the pervading dilemmas in his speech and thus following the suit of others before him. Whatever his reasons may be for such perplexing statements, Douglass consistently pointed to The Declaration of Independence and the Constitution "framed by the illustrious fathers" for the origination of these double senses. Jacques Derrida attributes the contradictory dualities to the co-existence of performative and constative structures embedded within these two fundamental legislative and executive texts of the United States (Derrida, 1984, p. 21). Comprised of performative sentences, utterances that perform an action rather than describe a situation, The Declaration of Independence acted on the social reality and created conditions defining the new American. The famous preamble to the declaration, "We hold these truths to be self-evident, that all men are created equal, that they are endowed by their Creator with certain unalienable Rights..." accomplishes the task of such a performative speech act whose abuse, for J. L. Austin, results in "unhappiness" for performative utterances are neither true nor false statements and can be declared null and void in response to a constative assertion or to an incompatible social reality (Austin, 1962). Perhaps recognizing such paradox, the authors of the declaration felt the need to finish the preamble with "the pursuit of happiness," which according to Slavoj Zizek, is a modified version of John Locke's natural rights of life, liberty and property and the last phrase is replaced by pursuit of happiness "as a way to negate the black slaves' right to property" (Zizek, 2008, p. 493).

\section{Conclusion}

As the US nation emerged from a world in which power was embodied in the person of the crown, to one in which power vested in the people, blacks were consequently assigned to the former subjugated position that whites were held under the British rule. In this regard, nothing seems to have changed since the Revolution save the role and the number of the actors (rulers) in the following years. Even though the infant state showed the due signs required of a Habermasian bourgeois public sphere, rising from the ashes of a feudal system, it nevertheless made clear in all its private, social, legislative, and imagined discursiveness that there could be no place of citizenship for the emancipated blacks or half million slave population. All segments of the US society seemed to work in a complementary way to ever alienate, demonize and dislodge a population to the farthest end of the 
spectrum of invisibility. Nash's question in the initial pages of this article seems hollow or at least utopian at this point. Emancipation was not just a simple matter of breaking the chains of bondage of the enslaved African-Americans and did not end there. When Jefferson was working in his dimly lit room on the first draft of the Declaration, he was probably not imagining Africans as one out of many to pursue liberty and happiness. Or when Madison and Washington were condemning the system, they were not probably doing so out of a concern to give the blacks the same status as the fellow whites enjoyed. How else could their silence and reluctance, and the ambivalence of the Quakers be explained?

The American Revolution did draw the boundaries and those actual boundaries decided the ultimate fate of a race and made the emancipation an illusory project. More than that, those boundaries made race a legitimate and a vital register of becoming a member - citizen - of the society in the ensuing years. It dawned earlier on James Forten, a black patriot who fought in the war, that "black Americans could achieve peoplehood and nationality only by becoming something other than Americans" (Nash, 2006, p. 144). Seventy-six years after the year 1776, Frederick Douglass was delivering the same agonizing truth to an anti-slavery audience in Corinthian Hall, Rochester: "This Fourth July is yours, not mine. You must rejoice, I must mourn" (Douglass, 2015, p. 7). The revolution marked the beginnings of a nation in miscellaneous and ambiguous ways. In its trail, it brought a hard-earned freedom, a glorious national discourse that Americans would memorize and solemnize to acknowledge their peoplehood. However, it was also a watershed moment in the national history that left its legacy as one ponderous, haunting contradiction to be resolved for the next two and a half centuries. ${ }^{4}$

Grant Support: The author received no financial support for this work.

4 Ever since the American Revolution and the Declaration of Independence, duplicity has been a benchmark word for the African American communities. In 1903, W. E. B. Du Bois introduced the concept of double consciousness to explain the conflicts in African-American subjects who had to live with "the sense of looking at one's self through the eyes of others" (351). In 1963, Martin Luther King Jr. called for an end to double-standards based on race and asked the US society to live up to the "true meaning of its creed" as was drawn out in the declaration. The Black Panther party rephrased the preamble and saw it as their right and duty "to throw off such government, and to provide new guards for their future security." Civil society movements such as Black Lives Matter, formed after the murders of African American individuals by the US police in 2013, 2014 and 2015 are the living testimonies of bridging the color gap that still divides American citizenship along racial lines. 


\section{References}

Anderson, B. (2006). Imagined communities: Reflections on the origin and spread of nationalism. New York: Verso Books.

Austin, J. (1962). How to do things with words. Oxford: Oxford University Press.

Colaiaco, A. J. (2006). Frederick Douglass and the fourth of July. New York: Palgrave Macmillan.

Derrida, J. (1984). Otobiographies. Paris: Galilee.

Douglass, F. (2015). What to the slave is the fourth of July? South Carolina: Another Leaf Press.

Genovese, E. (1988). The world the slaveholders made: Two essays in interpretation. New York: Pantheon Books.

Habermas, J. (1991). The structural transformation of the public sphere: An inquiry into a category of bourgeois society. Massachusetts: MIT Press.

Jameson, J. F. (1973). The American revolution considered as a social movement. New Jersey: Princeton University Press.

Jefferson, T. (1905). The works of Thomas Jefferson, vol. 1. New York: The Knickerbocker Press.

Jordan, W. (1968). White over black: American attitudes toward the negro, 1550-1812. Chapel Hill, Va. : University of North Carolina Press.

Kaminski, P. J. (1995). A necessary evil? slavery and the debate over the constitution. Wisconsin: Madison House Publishers.

Marx, K. \& Engels, F. (1964). The north American civil war. Moscow: Progress Publishers.

Nash, B. G. (2006). The forgotten fifth: African Americans in the age of revolution. Massachusetts: Harvard University Press.

Osborne, P. (2003). It is time for us to be up and doing. In M. Pohlmann (Ed.), African American political thought: Integration vs. separatism, the colonial period to 1945 (pp. 7-11). London: Routledge.

Patterson, O. (1999). Rituals of blood: Consequences of slavery in two American centuries. New York: Basic Civitas Books.

Tannenbaum, F. (1963). Slave and citizen: The negro in the Americas. New York: Vintage Books.

Warner, M. (2002). Publics and counterpublics. Quarterly Journal of Speech, 88:4, 413-425.

Wood, S. G. (1993). The radicalism of the American revolution. New York: Vintage Books.

Wood, S. G. (2011). The idea of America: Reflections on the birth of the United States. New York: The Penguin Press. Zizek, S. (2008). In defense of lost causes. New York, US: Verso Press. 